\title{
Quando a fotografia (já) fazia os antropólogos sonharem: $O$ jornal La Lumière (1851-1860) ${ }^{1}$
}

\author{
Étienne Samain \\ Professor do Programa de Pós-Graduação em Multimeios do Instituto de \\ Artes e Coordenador Científico do Centro de Memória (CMU) - Unicamp
}

RESUMO: Na efervescente metade do século XIX, marcada pela febre da ordem e do progresso, da racionalidade e das luzes, os antropólogos-naturalistas franceses descobrem, ao lado de muitos outros cientistas, as possibilidades heurísticas que a fotografia ofereceria à "visão" que eles tinham da "antropologia", a saber essa tentativa de mapeamento da "espécie humana", das raças e, dentre elas, dos tipos humanos, numa perspectiva claramente evolucionista.

O jornal La Lumière (1851-1867), primeira publicação francesa dedicada à "Fotografia, às Artes e às Ciências", foi parcialmente reimpresso em 1995. Mergulhando nas colunas desse semanário, o leitor, além de adquirir uma idéia das origens da antropologia francesa, descobre as profissões de fé que se erguem em torno do novo suporte técnico e da nova "retina do cientista". Descobre, também, como essa prótese instaura uma nova ordem do olhar e levanta, em termos de uma epistemologia do conhecimento, um interessante questionamento em torno de dois outros meios de representações figurativas nos círculos antropológicos da época: os desenhos e as moldagens.

PALAVRAS-CHAVE: Antropologia visual francesa no século XIX, jornal La Lumière (França), meios de representações figurativos, Vênus hotentota.

La Lumière foi a primeira publicação francesa dedicada à fotografia. A primeira a alimentar um debate que, desde a divulgação da sua invenção (1839), a fotografia não cessou de levantar - situada que estava, na encruzilhada de "três pólos de interesses contraditórios": as Belas Artes, 
as Ciências e a Indústria. Durante exatos 17 anos, de 1851 a 1867, La Lumière dará conta deste debate, apaixonante e múltiplo, no meio de suas próprias vicissitudes editoriais, reestruturações e tensões internas.

Passados 150 anos, pode-se imaginar que este monumento dos arquivos fotográficos permanecia, na sua totalidade, de difícil encontro e reconstrução. Existiam, aqui e acolá, exemplares anuais incompletos. Fazia-se necessário localizar, cruzar e reunir um material disperso e, desta maneira, ressuscitar o que tinha sido La Lumière. Precisava-se, sobretudo, de um editor, audacioso e perspicaz, para que - com o apoio do Ministério da Cultura e da Francofonia e de outras entidades européias - tal empreendimento pudesse se tornar realidade. A reimpressão do jornal (com uma tiragem limitada a 300 exemplares) efetivouse, no final do ano de 1995, sob a forma de dois importantes volumes encadernados, no formato $25 \times 35$, totalizando mais de duas mil páginas. Esta reimpressão que cobre a época áurea de La Lumière (1851-1860), mereceu uma longa e notável "Apresentação" (vol. 1: 9-32) de Gilbert Beaugé, pesquisador do Centro Nacional de Pesquisa Científica (CNRS de Aix-en-Provence), que assina, também, o precioso "Índice" (vol. 2: 22 últimas páginas) dos nomes citados (infelizmente não das temáticas abordadas) no La Lumière durante os dez anos em pauta.

Tratando-se de uma documentação extensa, tão riquíssima quanto instigante, aberta a um horizonte infinito de leituras e de mergulhos possíveis, temos de, necessariamente, delinear os contornos de uma primeira aproximação. Escolhemos tratar, aqui, das "figurinhas" que, na efervescente metade do século passado, a fotografia e a antropologia partilham e trocam, no La Lumière, tanto em termos de sonhos quanto de realidades. Antes de se chegar lá, parece-nos necessário evocar brevemente o espírito do tempo na França do Segundo Império e precisar o que, na época, representa a Antropologia. Poderemos, dessa maneira, entrar no bojo desta pesquisa, tomando conhecimento das profissões de fé no potencial heurístico de uma fotografia que está apenas nascendo; descobrindo, também, como esse suporte instaura, 
além de uma nova ordem do olhar, uma interessante problematização em torno de dois outros meios de representações figurativas da época: os desenhos e as moldagens.

\section{O jornal La Lumière: breves considerações}

La Lumière. Jornal não Político. Belas-artes, Heliografia, Ciências sai, em Paris, pela primeira vez, num domingo, 9 de fevereiro de 1851. A nova publicação que, até certo ponto, era uma emanação da Sociedade Heliográfica, criada no mesmo ano, foi dirigida, num primeiro momento, pelo coronel Benito de Montfort e pelo padre F. Moigno. Ela se dava como objetivo responder "ao desejo ardente de [fazer] conhecer o que as ciências, as belas-artes e as descobertas trazem cada dia de tesouros no centro da civilização (...). É ao homem do mundo das capitais, às doutas sociedades das cidades, ao artista solitário de nossos departamentos, que se dirige esse jornal (...). La Lumière será fiel ao seu título(...) antes de mais nada nossa tarefa será a de examinar o que é bom, belo, interessante e novo" (La Lumière, 1851, n.1: 1). "Livres de toda preocupação política, de todo interesse nacional, devemos ser o eco das doutas sociedades da França e do exterior. Toda descoberta interessante (...) encontrará espaço nas nossas colunas, todo homem de mérito terá o apoio de nossas publicações" (n.2: 5).

Os objetivos traçados neste in-fólio semanal não são apenas esclarecedores do espírito do tempo mas sobretudo definem como se concebia, nos meados do século passado, a fotografia. Ela era, ao mesmo tempo, uma ciência, uma arte e uma indústria. A fotografia prendia-se às ciências pelas suas relações de origem com a química e a física. Ela se tornava uma nova expressão da arte através de suas obras que eram a "imitação a mais verdadeira da natureza". Representava, finalmente, uma nova mercadoria e uma nova indústria. Essas crenças repousavam e alimentavam um verdadeiro credo: 
Acreditamos, desde que a clareza se fez sobre uma primeira cegueira, de todas as forças de nossa convicção, a este advento solene da fotografia, como acreditamos às leis do progresso, como acreditamos em todas as boas coisas que apraz à Providência nos revelar, a cada passo do mundo no decorrer dos tempos, para o aperfeiçoamento indefinido das gerações. Essa fé santa e religiosa é para nós um consolo e uma esperança. (La Lumière, 1852, n.39: 155)

Por razões, hoje, de difícil esclarecimento, mas que, por certo, colocam em jogo tráficos de influência, vaidades pessoais e interesses comerciais, o número 38 do La Lumière, datado de 29 de outubro de 1851, informa secamente a seus alguns trezentos primeiros assinantes que "O jornal La Lumière não será mais publicado" e que "Os Senhores assinantes, cujo preço de subscrição não tenha sido compensado pelos anúncios publicados receberão em dinheiro a diferença de suas assinaturas, no escritório do jornal, na rue de l'Arcade, $\mathrm{n}^{\circ} 15$, durante todo o mês de novembro, das dez da manhã às treze da tarde, com apresentação de seus recibos de assinatura". Um engajamento que, na realidade, não se concretizará e conduzirá os novos donos a entrar, mais tarde, na justiça. Mas quem são esse novo "gerente proprietário" e esse novo "redator-chefe"?

O primeiro, Alexis Gaudin, um afeiçoado por fotografia, tem em Paris (rue de la Perle, $n^{\circ}$ 9) sua fábrica e sua loja de "artigos e utensílios necessários aos fotógrafos, em condições e com preços muito vantajosos, além de ser de uma qualidade comprovada" e, em Londres, uma sucursal situada no número 67 da Newgate Street. Se o esperto comerciante Gaudin sabe escolher até os nomes das ruas para os seus pontos de venda, não ignora, também, como oferecer ao jornal La Lumière novos canais e horizontes críticos. Desde o começo do ano de 1852, La Lumière publicará, quase que semanalmente, além das interessantíssimas crônicas das Atas da Academia das Ciências de Paris, informações oriundas de sociedades fotográficas que, na Inglaterra, na Alemanha, na Itália, nos Estados Unidos, nascem na mesma época, abrindo um vasto campo de debates em torno dos sucessivos aperfeiçoamentos dos 
processos fotográficos e dos múltiplos usos que a fotografia deveria oferecer às ciências.

É verdade que Gaudin pode contar com Ernest Lacan, seu redatorchefe, homem de particular qualidade intelectual que o acompanhará até 1861 . Esse crítico parisiense, reúne, nas terças-feiras, em seu apartamento, o mundo das artes e das ciências. Falando várias línguas, ele é durante dez anos a cravelha mestra do La Lumière. Ele é um crítico; Gaudin, apenas um marchand.

O jornal La Lumière apagar-se-á em 1867. Ele teve e guarda o mérito de poder reconstituir "o clima epistemológico dentro do qual a fotografia se desenvolveu" na metade do século passado (Beaugé, 1995, vol. 1: 16). 
PREMIERB ANNEE. No: 25

\section{LA LUMIÈRE}

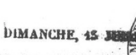

JOURNAL NON POLITIQUE

HETDOMADARE.

\section{BEAUX-ARTS - HÉLIOGRAPHIE - SGIENGES.}

bUREaUX, a paris, No15, RUE de l'ARCade, a La société heliographiQUe.

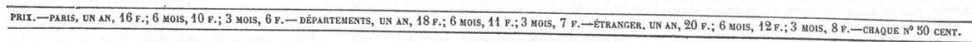

\section{MORT DE M. DAGUERRE.}

La dernière séance de la Société héliographique a été attristéc par une aflligeante communication : un membre du Comité des artistes-peintres est venu nous faire part de la mort de M. Daguenas. Cette perte sera vivement ressentie par toutes les personnes qu'intéresse l'avenir d'une science rcdevable à M. DAGUEaı des admirables perfectionnements qui l'ont rendue populaire. Artiste distingué, esprit novateur, pensée active . et persévérante, Daguenre étail encore dans la vigueur de l'àge, et il aurait acquis de nouveaux titres à la reconnaissance de ses contemporains, si la Providence eût prolongé sa laborieuse carrière.

Unè députation de la Sociélé héliographique, a laquelle se sont joints la plupart de nos confrères, s'est rendue hier au convoi funèbre de cet homme éminent, où se pressaient les sommités de l'art, des lettres et de la science. Le journal la Lumière consacrera prochainement une notice biographique au regrettable inventeur qui partage avec Niépce la gloire d'avoir accompli l'une des plus surprenantes découvertes du dixneuvième siècle. F. WEY.

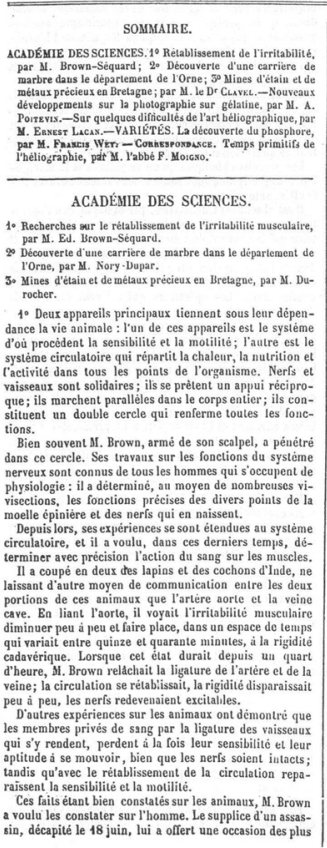

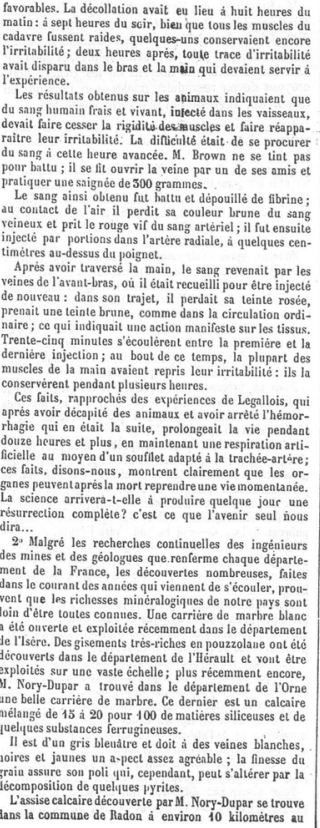

nord d'Alencen : elle occupe une surface considérablé, et peut rivaliser pour les travaux d'ornementation avec les Calvados: elle peut en outre fournir de la Mayenne et le et rendre, sous ce rapport dimare de pierre i chaux trie du bátiment et í l"ariculturo.

$5^{\circ}$ Des richesses minéralogiques d'un antre ondre ont donné lieu aus recherches de II. Durocher: il vient explorer de la foçon la plus minutieuse les alluvion stanuifêres situées dans la Loire-Inférieure et te Morbihan sur presque toute la zone littorale qui sépare l'embou-

Les dépôts superficiels contiennent de l'oxyde d'étain en assez grande abondance pour donner licu, sur quelques a la surface el sur le pourtour du massif esratie mém sépare la vallée de l'Oust de celle de la Claye.

On rencontre l'oxyde d'ćtain tantỏt en petíts grain arrondis, tantót sous forme de couleur noir brun, violaceé, blanche el d un jaune-citron. Les échantillons trans lacides et à teinte claire sont presque aussi purs que oryde detain prepare artiacieltement, tandis que les ou de nanganese.

A l'oxyde d'étain contenu dans les dépỏts d'alluvion de la Bretagne s'adjoigaent quelques paillettes d'or: un mé-
tre cube de sable de la cóte de Pénestin renferme 10 i 15 kilogrammes d'oxyde d'étain, et environ un demi-gramme d'or ou un peu plus: les graviers auriferes que l'on exploite dans le lit du Bhin ne sont pas aussi riches. Dans un autre dépót d'alluvion, ou l'or est en plus grande quantité qu'a l'énestin, dépôt situce dans la vallée des forme de globules liquides, tantót amalgamé avec de loou et de l'argent.

Les travaux de MI. Durocher offrent un vif intérét: its démontrent que les veines slanniféres ne sont pas exclusivenient contenues, en Bretagne, dans la zone de séparation des schistes et des granits, comme on le croyait jusqu ia ce jour; puisque de l'oxyde d'élain a été rencontré a que certoines berties des granits. lls démontrent encore métaus qui la rendent sol de la France renferment des sommes considerables.

NOUVEAUX DÉVELOPPEMENTS SUR LA PHOTOGRAPHIE SUR GÉLATINE,

PAB M. A. Pourevis.

a. Depuis que M. Balard m'a fait l'hooneur de commumai 1850 , mon proces sciences, dans la séance du 27 me suis appliqué, autant qu il m'a été possible, i i moditier ce procédé, pour rendre la préparation de la plaque gélatinée moins longue, et d'un résultat plus assuré.

Fac-símile do La Lumière (domingo, 13 de Julho de 1851), anunciando a morte de Louis Daguerre. 


\section{A França no Segundo Império (1852-1871)}

Em 02 de dezembro de 1852, o Segundo Império ${ }^{2}$ se instala na França. Inicia-se um período de vinte anos, sob o governo do príncipepresidente, Luis Napoleão III, sobrinho de Napoleão I. Um período que refletirá os avanços de duas revoluções: a Revolução Francesa de 1789 e a Revolução Industrial. Um Império que desabará num banho de sangue: não somente a guerra franco-alemã mas, sobretudo, numa Paris assediada e faminta, o levante dos partidários da Comuna (1871) e as execuções sumárias.

Gestada na Inglaterra, a Revolução Industrial alastra-se, há mais de oitenta anos, pelo continente inteiro. No seu bojo, carrega energias e paixões que vão transformar em profundidade o tecido e os rumos da estrutura social até então existentes. Esta Revolução significa o desterro da alta burguesia e da aristocracia e o advento no poder de uma pequena burguesia liberal, constituída por proprietários fundiários, financiadores e banqueiros, manufatores, fabricantes e empreiteiros. Significa, também, a explosão de uma sociedade agrária feudal tradicional, a penetração da economia de mercado no mundo rural ao mesmo tempo em que ocorre uma emigração cada vez maior dos camponeses para os centros urbanos que precisam de mão-de-obra e de novos consumidores. Significa, enfim, no palco sociocultural da época, a emergência de uma jovem classe operária industrial (movimentos trabalhistas e socialistas), além de uma explosão demográfica sem precedentes na Europa. Para se ter uma idéia do movimento populacional na cidade de Paris, em 1856, eis o que comenta La Lumière:

A população da cidade de Paris (intramuros) era, em 1856, de 1,130,488 (um milhão cento e trinta mil quatrocentos e oitenta e oito). Nasceu em Paris 19,200 meninos e 18,568 meninas (...) desses 9,780 são naturais. Mais de um quarto das crianças nascidas em Paris! (...) A população da França é de 36,039,364 (...). Se o crescimento de um 222 décimos se mantivesse o mesmo, a população aumentaria de um décimo em 24 anos, de dois décimos em 41 anos, de três décimos em 58 anos, de quatro décimos em 75 anos, da metade 
em 90 anos. Ela poderia, então, ser de pelo menos cinqüenta milhões em 1956³. (n.4: 14)

Essa revolução das estruturas econômicas e sociais acompanha e alimenta-se de uma dupla ideologia: a do progresso e a da racionalidade.

Pode-se dizer que, nos meados do século XIX, a França e a Inglaterra em particular, vivem de uma mesma febre: a mística da velocidade e das aberturas. É preciso ser veloz como a energia elétrica descoberta em 1786, potente como o vapor que, em 1825, faz “decolar" o primeiro trem de passageiros ingleses, puxando suas 90 toneladas numa velocidade de $20 \mathrm{Km} / \mathrm{h}$. É necessário, após a abertura das "passagens"4 às servidões mundanas de Paris desde os anos de 1820, redesenhar por completo a fisionomia de uma cidade que, com os seus labirintos de vielas estreitas (que favorecem a construção das famosas barricadas), quase não mudou desde 1789. G. Haussmann, prefeito de Paris de 1853 a 1870, vai desventrar a velha cidade, cortando-a num duplo eixo, traçando as largas avenidas e os bulevares que conhecemos hoje, abrigando no seu centro a nova classe industrial dirigente e contendo na periferia o quase meio milhão de operários que nela já se concentra ${ }^{5}$.

É necessário assegurar, também, o progresso na velocidade dos transportes e dos meios de comunicação. Entre 1800 e 1840, a França abre $3.300 \mathrm{Km}$ de canais e, de 1850 a 1880 , as vias ferroviárias exploradas no país passam de 2.000 a $24.000 \mathrm{Km}$, impulsionando uma produção de grande escala, ao alcance do maior número. A primeira conversa telegráfica entre a França e a Inglaterra data de 1851 e tem como palco - não por acaso - a primeira Exposição Universal de Londres. A maquinaria é onipresente, alimentada pelas minas de carvão e pela pesada siderurgia em plena expansão. A Europa industrial vibra por todos os seus poros. Nada poderá parar os avanços da indústria, conquista do espírito e novo templo do progresso da humanidade.

Os embelezamentos de Paris prosseguem com uma atividade que tem tudo a ver com o prodígio; o fotógrafo tem apenas o tempo de transportar sua objetiva de um ponto para outro: eis aqui a praça Louvois transformada 
Revista de Antropologia, São Paulo, USP, 2001, v. 44 nº 2.

em alguns dias num jardim gradeado (square) delicioso; lá, a ponte de Solferino, iniciada em 15 de agosto de 1858. (...) Essa ponte, de 100 metros de comprimento e 20 de largura, desemboca numa nova entrada das Tuileries, na parte a mais sombreada; tem-se o sentimento de penetrar no Parque de Versailles ou de Fontainebleau. (...) O gênio humano anda, anda mais ainda, anda sempre... Continuem por favor, vocês todos operários do pensamento, subvertam o mundo, perfurem as montanhas, encham os vales, façam comunicar os mares; e, vocês, mecânicos, reduzam as distâncias, suavizem o trabalho, centupliquem as forças; e, vocês, químicos, liquidifiquem os metais, misturem, triturem, amalgamem, e por mais poderoso que seja vosso gênio, por maior que seja vossa ciência, não esperem jamais fazer dizer à natureza a sua última palavra ${ }^{6}$. (La Lumière, 1859, n.36: 142-3)

Inseparável dessa mística da velocidade e do progresso, a racionalidade é, durante o Segundo Império, mais do que uma virtude. Ela participa diretamente do credo positivista de Auguste Comte $^{7}$ e da confiança inabalável na capacidade de progresso humano. Não se trata apenas de racionalizar a organização das atividades para fazer crescer a produção, acumular os proveitos, se enriquecer e subir na escala social; trata-se de construir a experiência a partir do conhecimento único dos fatos, isto é, a partir de uma rigorosa observação dos mesmos.

É, dessa maneira - escreve André Rouillé (1982) - "que tanto na França como na Inglaterra se constitui a ideologia racionalista e progressista das Luzes que, em face das tradições herdadas da Idade Média, à superstição das Igrejas e à irracionalidade da hierarquia social fundada no nascimento, vangloria os méritos das ciências, das técnicas, do bem-estar, da civilização em via de edificação" (: 16).

É no horizonte deste duplo processo de construção do novo poder econômico, político e ideológico da burguesia "esclarecida", que devemos situar a descoberta da fotografia e as múltiplas invenções de que será agente e suporte.

Exibição do triunfo burguês presente no cenário de metrópoles em plena transformação, a fotografia servirá tanto para firmar essa nova identidade social como para fazê-la circular. Particularmente representativo desse duplo imperativo é o "cartão de visita" ou "retrato- 
carta", que representará, a partir de 1860, uma nova moeda de troca ao mesmo tempo que se constituirá em uma verdadeira enciclopédia visual da sociedade do Segundo Império.

Paralelamente, a fotografia se investirá de toda uma missão civilizadora na medida em que, também, se torna capaz de "espalhar as luzes nas multidões, para elevá-las e torná-las melhores" (Revue Photographique, 1862: 151 apud Rouillé, 1982: 147). As expedições exploratórias se multiplicam com uma intensidade ímpar ${ }^{8}$. Em Paris e nas províncias se instalam missões fotográficas subvencionadas pelos governos central ou local e os documentos trazidos dos quatro cantos do mundo se tornam, com as Exposições Universais", as novas vitrines e as "olimpíadas" do conhecimento e do progresso. Nadar (1820-1910) tem razão ao escrever: "Vivemos numa época de curiosidade exasperada que escava tudo, homens e coisas. Na falta da grande história que não conseguimos fazer mais, recolhemos as migalhas da pequena com tanto zelo que nossa consideração chegou a arregalar seus grandes olhos diante de um colecionador de selos postais" (1994: 230).

\section{A antropologia francesa da época}

A antropologia francesa, em meados do século passado, pertence ainda ao vocabulário da anatomia e permanece relacionada à zoologia, da qual ela representa a necessária excrescência. A cátedra que a designa no Muséum d'Histoire Naturelle de Paris e da qual, em 1838, o médico Pierre Flourens (e um ano depois, Étienne Serres, outro médico, de que voltaremos a falar adiante) torna-se titular, chama-se "Anatomia e História Natural do Homem”. Uma denominação que reflete e traduz todo um projeto de apreensão e de compreensão da espécie humana, objeto de um debate que perpassa todo o século XVIII (Duchet, 1971), nutrido pelas reflexões de filósofos e de naturalistas, tais como Voltaire (1694-1778), Jean-Jacques Rousseau (1712-1778), o sueco Carl von Linné (17071778), mas que, no caso da antropologia francesa, parece claramente 
Revista de Antropologia, São Paulo, USP, 2001, v. 44 nº 2.

se originar a partir das idéias desenvolvidas por Georges-Louis Buffon (1707-1788), autor (com os seus colaboradores) dos 36 volumes da História Natural do Homem, o primeiro tratado sistemático de antropologia (publicado a partir de 1749). Buffon, empirista e homem de gabinete, sempre bem informado, procura, na sua época, empreender o inventário da condição humana em diferentes climas e em diversos estágios de evolução das sociedades.

A antropologia do Segundo Império (e os que a exercem ${ }^{10}$ ) é, dessa maneira, parte de uma história natural dos seres vivos (homens e animais) situados num mesmo meio biológico: a terra. Um universo no qual o homem, no entanto, é o "ser único e superior por essência”, já que todos os outros seres que o povoam "submetem-se à sua lei” (Buffon).

Nos rastros de Buffon, essa antropologia reivindicará duas coisas de particular relevância. A primeira é significativa em termos teóricos: há de se buscar, antes de mais nada, as características físicas que definem a espécie humana, cujas raças (européia, negra, chinesa e americana [Buffon]) representam apenas as "variedades" ou "variações" de uma espécie humana, distinta, todavia, da espécie animal. A segunda é fundamental em termos metodológicos: a nascente antropologia define a questão da observação: é preciso saber ver, aprender a olhar, precisar e definir de que lugar e sob que ângulo enfocamos o nosso olhar, munir-se de instrumentos tecnológicos capazes de oferecer o registro o mais objetivo e preciso possível dos tipos de todas as raças humanas e dos caracteres fisionômicos distintivos de cada uma delas.

Para completar o horizonte dos questionamentos que, na época, agita os meios científicos em torno de uma elucidação da história natural dos seres vivos, convém lembrar que, decorrente de um apego (disciplinado e sancionado) a toda uma tradição bíblica, uns defendem o monogenismo (teoria segundo a qual todas as raças humanas derivariam de um único casal primitivo), enquanto outros apelam para o poligenismo (teoria segundo a qual a humanidade atual seria o resultado de vários focos originários de vida). Não se deve esquecer, sobretudo, que aos defensores 
da teoria do transformismo do biólogo francês Jean-Baptiste Lamarck (1744-1829) (teoria que formula a hipótese da origem animal do homem $^{11}$ ) juntam-se os novos adeptos de uma filosofia zoológica, melhor formulada pelo inglês Charles Darwin (1809-1882), autor do famoso A origem das espécies (1859) ${ }^{12}$, para quem seleção natural e luta pela vida desempenham um papel determinante na constituição dessas espécies.

Nesse contexto, claramente evolucionista, não é de se espantar, enfim, que Karl Marx (1818-1883) e Friedrich Engels (1820-1895), por outras razões, publiquem em Paris em 1848 o Manifesto do Partido Comunista, transpondo o discurso de uma história natural dos homens nos termos concretos de uma história social: "O proletariado passa por diferentes fases de evolução. Sua luta contra a burguesia começa com sua própria existência” (Marx, 1965: 169) ${ }^{13}$.

\section{A “espécie humana” e o daguerreótipo}

Essas considerações preliminares nos permitem avançar e adentrar a concretude de alguns textos que nos oferece o jornal La Lumière, no período de 1851 a 1860. Num primeiro momento, trata-se de reencontrar os termos da antropologia que defende Étienne Serres, professor do Muséum e membro da Academia das Ciências, e a esperança que deposita no progresso do daguerreótipo. Em seguida, acompanharemos, com Henry Milne-Edwars, outro naturalista do Muséum, os esforços de fotógrafos que, como Louis Rousseau, se empenham com "zelo, habilidade e abnegação", em tentar representar os "animais raros das coleções do Muséum d'Histoire naturelle de Paris”. Será possível, no término desse percurso, levantar algumas considerações de conjunto e, ao focalizar a esteatopigia (acúmulo excessivo de gordura nas nádegas) da Vênus hotentote, repensar a questão das representações figurativas do saber antropológico nos meados do século XIX.

Em 1853, o Muséum d'Histoire Naturelle ${ }^{14}$ recebe, do príncipe Demidoff da Academia das Ciências de São Petersburgo, uma coleção composta 
Revista de Antropologia, São Paulo, USP, 2001, v. 44 nº 2.

de 59 figuras miniaturadas, representando as raças humanas presentes no vasto império russo. Essa "iconografia plástica em miniatura" abarca ao mesmo tempo "as raças cristãs, as raças maometanas, os judeus, os idólatras e os tipos do pólo ártico”. Se tal tipologia pode nos fazer sorrir hoje, tratando-se de uma enumeração "confessional" e não científica das raças humanas, o importante presente recebido oferecia a oportunidade ao Doutor Étienne Serres de lembrar, diante da Academia das Ciências de Paris, a "origem da implantação de uma cátedra de anatomia e de história natural do homem", nesses termos:

Ao tomar a iniciativa de uma cátedra de antropologia no Muséum, a França seguiu o impulso dado desde um meio século às ciências naturais pelos progressos da anatomia geral e comparada. Deu novamente vida a uma ciência morta, e o movimento novo que lhe imprimiu interessa ao mesmo tempo à humanidade, à filosofia e à civilização. O resultado definitivo da organogenia geral e comparada, aplicada ao estudo físico do homem é o de separá-lo nitidamente da animalidade, e de fazer dele um reino à parte, o reino bumano. Ora, a partir do momento em que o homem fica excluído do reino animal, assim como já Aristóteles o tinha estabelecido, torna-se indispensável para (co-)ordenar seus diversos tipos, reuni-los numa galeria especial, a fim de ter constantemente diante dos olhos os elementos da observação.

Esse exame direto e comparativo é, com efeito, indispensável, na antropologia, para resolver, baseando-se nos fatos, os problemas tão difíceis e tão importantes que se constituem em seu fundamento, a saber: $1^{\circ}$ ) a unidade primitiva das raças humanas; $2^{\circ}$ ) sua aparição numa região da terra; $3^{\circ}$ ) sua dispersão sobre a superfície do globo; $4^{\circ}$ ) sua filiação, isto é, o estudo da gradação ou da degradação dos caracteres físicos que especificam o homem e fazem dele um ser distinto do resto da animalidade ${ }^{15}$.

Por meio dessa análise e na presença dos tipos, poder-se-á buscar enfim como, partindo de um tronco comum, as variedades humanas se desenvolveram, ora seguindo uma linha de aperfeiçoamento, ora, ao contrário, seguindo uma linha de degradação. Poder-se-á, deste modo, subir e descer na escala humana, procurando ligar, nos seus diversos degraus, a história dos povos e das nações com relação aos quais a parte etnológica da antropologia reuniu materiais tão preciosos" (La Lumière, 1853, n. 47: 186).

Um ano antes, o mesmo Étienne Serres fora designado para compor uma comissão da Academia das Ciências de Paris, encarregada, pelo 
Ministro da Instrução Pública, de oferecer subsídios e "instruções relativas à antropologia e às disciplinas que a ela se relacionam", instruindo os membros de uma "expedição científica a ser enviada ao interior da América do Sul, sob a direção do Sr. Emile Deville”. Sob o título "Fotografia Antropológica", o jornal La Lumière relata o seguinte:

Eis o trabalho do Sr. Serres, que representa um tratado muito interessante sobre a matéria:

"A história natural do homem, ou o estudo das raças humanas, é particularmente recomendado ao Sr. Deville na missão que lhe é confiada na expedição científica no interior da América do Sul."

"Esse ramo de nossos conhecimentos se compõe de duas partes: da antropologia e da etnologia."

"A antropologia determina as condições físicas que separam o homem da animalidade, reconduzindo a diversidade das raças à sua unidade primitiva." "A etnologia abraça a determinação das relações entre raças diferentes, sua filiação, sua disseminação e sua mistura na superfície do globo."

"A primeira é mais intimamente ligada à zoologia, a segunda à história.

Essas instruções dizem respeito apenas a alguns pontos da história natural do homem."

"A representação fiel dos tipos humanos está na base da antropologia; obtémse através de dois procedimentos que nada deixam a desejar: o daguerreótipo, de um lado, e a moldagem dos bustos com gesso, do outro."

"Com poucas exceções, os viajantes nos transmitiram os tipos americanos e o fizeram de uma maneira ideal: quase sempre as figuras que se encontram nas suas obras são os tipos europeus vestidos à maneira americana. A arte brilha, sem dúvida, mas à custa da realidade. Ora, é essa realidade, toda nua e sem arte, que nos fornece o daguerreótipo, o que dá às figuras obtidas por esse meio uma certeza que nenhum outro meio saberia substituir."

"Não poderíamos, assim, deixar de recomendar muito aos nossos viajantes a utilização deste processo e a multiplicação dos tipos registrados sobre o homem e a mulher adultas, bem como sobre as crianças."

"Após o daguerreótipo, a reprodução dos tipos pela moldagem em gesso ao vivo é de uma exatidão tanto mais preciosa, que reproduz ao mesmo tempo o tipo e as dimensões da cabeça, do pescoço e dos ombros. Uma vez obtidas essas dimensões, torna-se fácil, a partir da correlação das partes, deduzir as dimensões daquelas que o gesso não pôde representar". (1852, n.33: 130, grifos nossos) 
Revista de Antropologia, São Paulo, USP, 2001, v. 44 nº 2.

Em março de 1853, Louis Rousseau (1788-1868), ajudante-naturalista no Muséum, e Achille Deveria (1800-1857), pintor no Museu Egípcio do Louvre, iniciavam a publicação de três fascículos de um trabalho fotográfico destinado a "acompanhar" (o termo é interessante ${ }^{16}$ ) os textos dos ilustres cientistas. Um trabalho composto de sessenta pranchas e intitulado a Fotografia zoológica:

A Fotografia zoológica é uma coleção das figuras reproduzidas a partir dos modelos fornecidos pelo Muséum d'Histoire Naturelle, destinadas a acompanhar os textos dos ilustres cientistas, cujos escritos propiciaram os tão importantes progressos das ciências naturais em nossa época. Essa coleção tem como finalidade colocar ao alcance de todos as reproduções obtidas através deste maravilhoso processo; reproduções tão fiéis que uma lupa basta para tornarem perfeitamente distintos caracteres que escapariam ao olho nu focado sobre o próprio objeto. (La Lumière, 1853, n.24: 34-5)

Esta publicação, que vai merecer toda a atenção e o apoio da Academia das Ciências, é objeto de um interessante relatório do zoólogo Henry Milne-Edwards (1800-1885), outro naturalista do Muséum. Trata-se, dessa vez, de evidenciar como e por que "essa arte nova é suscetível de oferecer às ciências naturais serviços que nem o desenho, nem a gravura poderiam alcançar":

Os corpos que o zoologista precisa representar oferecem, muitas vezes, uma profusão de detalhes que escapam ao olho nu e que, no entanto, devem ser mostrados. Para colocá-los em evidência, o desenhista tem de ampliá-los como se fosse através de uma lupa que os visse (observasse), de tal modo que as figuras ampliadas e assim obtidas raramente têm o aspecto desses objetos, tais como se apresentam na natureza. Para se ter deles uma idéia exata e suficiente, o zoologista precisa quase sempre de dois tipos de imagem: figuras de conjunto não ampliadas e figuras de certas partes características, mais ou menos ampliadas.

Nas pranchas fotográficas bem feitas (...) não se percebe os detalhes de estrutura quando se olha para elas com a simples observação direta, e os objetos representados conservam então seu aspecto ordinário; mas, quando se chega a examinar essas pranchas com a ajuda de uma lupa, vê-se nelas todos os detalhes que este instrumento faria ver no próprio objeto, e, conseqüentemente, aqui, uma única e mesma imagem representa ou contém as 
duas espécies de figuras de que acabamos de falar como sendo geralmente necessárias nas obras executadas com o pincel ou com o buril...

Em muitos casos, deve-se, também, levar em conta um outro fato que, a meu ver, é mais importante, e que é uma conseqüência da natureza mesma da operação fotográfica.

Quando o zoologista faz um desenho, ele representa apenas o que ele observa no seu modelo, e, conseqüentemente, a imagem traçada pelo seu lápis traduz somente a idéia mais ou menos completa que ele concebeu da coisa a ser reproduzida, de tal modo que é pouco provável que a figura assim obtida mostre com clareza os caracteres que o autor não terá levado em conta (...). Mas com a fotografia, a situação poderia ser outra. Pois uma imagem fotográfica bem feita oferece não somente o que o autor pessoalmente viu e quis representar, mas também tudo aquilo que está realmente visível no objeto assim reproduzido. Um outro naturalista poderá desta maneira captar dados que o primeiro não terá percebido e, graças à imagem, fazer verdadeiras descobertas, como teria feito observando o objeto ao natural ${ }^{17}$. (La Lumière, 1853, n. 24: 94-5)

O Sr. Milne Edwards apresentou [12 de Dezembro de 1853] à Academia, em nome dos Senhores Rousseau e Devéria o terceiro fascículo da Fotografia zoologica: se compõe de seis pranchas (...). Esses espécimen de espécies retiradas de todas as partes do reino animal dão uma idéia exata do poder dos meios utilizados, e provam que os autores conseguiram realizar as esperanças dos naturalistas, ao representar, com uma precisão até então desconhecida, todos os seres da criação. (n.52: 206)

Nesse panorama das novas funcionalidades heurísticas da fotografia com relação ao desenho, à gravura e às moldagens, não poderiam faltar considerações sobre as relações entre os artistas e os cientistas. Elas serão claras: a fotografia é uma arte que, todavia, não existiria sem a ciência e aqueles que a fazem.

Os doutos professores do Muséum, ao permitir aos artistas disporem de suas preciosas coleções, estimularam o zelo por estas. Do acolhimento benevolente dos sábios e do trabalho teimoso dos artistas resultou que a fotografia, que apenas modestamente entrou no esplêndido estabelecimento imperial, dele saísse triunfante. Ela espalha pelo mundo os tesouros da ciência, dá a todos, por quase nada, aos milhares, os espécimen de espécies raras e únicas, de que apenas alguns poucos privilegiados podiam dispor até o presente. Esse notável progresso, essa multiplicação milagrosa das provas foram justamente apreciados por ilustres cientistas. Por unanimidade votaram 
uma honrosa recompensa para os artistas que tinham colocado em prática os processos da gravura heliográfica sobre aço, indicados pelo Sr. Niépce de Saint Victor (...). O acolhimento favorável dado pela Academia à publicação da Fotografia zoológica, o encorajamento que ela outorga aos autores desta obra são de natureza a excitar a emulação dos artistas fotógrafos. Ambos os fatos evidenciam tudo o que a ilustre Sociedade está disposta a dar a todas as aplicações novas e úteis que forem submetidas ao seu veredicto e apoio. (La Lumière, 1854, n. 1:2)

\section{As novidades que a fotografia oferece}

A partir dos documentos que acabamos de ler, torna-se possível esboçar algumas considerações relativas às novas funcionalidades que a fotografia oferece a uma sociedade que respira o odor da ciência e o ardor do progresso, e cujo olhar enebriado, entretanto, nunca abdica da razão. A fotografia é, ao seu modo, a "tela informática" do século que estava por vir.

Nunca, sem dúvida, o caráter indicial da fotografia terá sido tão presente, na sua história, como no momento de sua aparição. A fotografia, na época, não é somente a "representação fiel" da realidade. Ela oferece, ou melhor, "fornece" a realidade em toda sua nudez ("a realidade toda nua", diz Serres). Essa mística da transparência e da objetividade que a cerca vai mais longe ainda. A fotografia é, no sentido pleno da palavra, uma "revelação". Ela "extirpa" e "preleva" no campo do real ou do saber fragmentos de uma realidade que o olho não consegue ou não sabe ver, de tal modo que "bastaria uma lupa para tornar perfeitamente distintos caracteres que escapariam a olho nu, posto sobre o próprio objeto". A fotografia, assim, não "mostra" apenas as coisas do mundo de uma maneira toda nova e com um rigor alucinante; ela as "revela" e torna passíveis de serem "descobertas".

Podemos, sem dúvida, pensar hoje em dia a fotografia a partir de outros parâmetros críticos. E no entanto não podemos minimizar o impacto provocado por essa nova invenção no âmbito de uma sociedade, 
tão positivista quanto esclarecida, que por meio dela descobria uma outra maneira de ver e de pensar o mundo. A revolução fotográfica instaurava uma nova ordem de visão e uma nova filosofia do olhar. Ela delineava novos campos da observação humana e, sobretudo, fazia nascer um novo tipo de observador (Crary, 1994). A revolução informática, que presenciamos e da qual estamos acompanhando os primeiros passos, poderia, talvez, nos ajudar a sentir e a medir o que representou o surgimento do suporte fotográfico em meados do século passado. A fotografia era, então, uma alma tão sensível como uma pele ou uma película. Uma indispensável e fulminante descoberta.

Esta profusão de objetividade e de indicialidade que carrega a fotografia em 1850 nos permite entender melhor por que ela foi empregada e encarregada de missões às vezes impossíveis no campo da Ciência. Uma coisa parece clara: a fotografia, em meados do século passado, está presente em todas as partes, seja nas ciências naturais ou humanas, quer seja nas ciências exatas. É um fato que permanece até hoje pouco explorado e estudado e que mereceria uma futura e aprofundada investigação. O jornal La Lumière é, deste ponto de vista, não apenas um arquivo impressionante como uma mina a céu aberto. Nele, pode-se perseguir, nas diversas crônicas semanais, as mais variadas aplicações da fotografia no campo da astronomia, da botânica, da biologia, da geologia, da zoologia, da história, da arqueologia, da geografia, da topografia, mas também no da cirurgia, da medicina, da psiquiatria etc.

Se naquela época a fotografia está em toda parte, sua utilização na antropologia reflete bastante claramente o que o mundo científico, de modo geral, espera dela. A fotografia fornece ao homem de ciência não somente indícios, traços, marcas, pistas, mas também “evidências" e, às vezes, até "provas". Que se trate de colocar ordem no dédalo das raças humanas e das espécies animais, que se trate de seguir as fases evolutivas ou regressivas de uma doença mental (H. W. Diamond, desde 1848) ou de documentar as etapas e os níveis de uma escavação arqueológica, a fotografia oferece ao cientista uma dupla vantagem: ela 
Revista de Antropologia, São Paulo, USP, 2001, v. 44 nº 2.

multiplica o campo de sua observação, colocando uma galeria de dados ao alcance dos seus próprios olhos; ela permite, sobretudo, o "exame direto e comparativo" desses dados. O cientista pode "ver de maneira constante, diante dos olhos, os elementos da observação". A fotografia torna-se sua nova retina.

A fotografia tem uma outra missão e um dos textos que vimos acima a define com clareza, não desprovida de ufanismo: "A fotografia espalha pelo mundo os tesouros da ciência, dá a todos, por quase nada, aos milhares, os espécimen de espécies raras e únicas, de que apenas alguns poucos privilegiados podiam dispor até o presente (...) (ela é) uma multiplicação milagrosa das provas". A fotografia não aproxima apenas o mundo, visível e invisível, do simples mortal, colocando sob os seus olhos aquilo que nunca tinha visto; ela se torna portadora de toda uma missão civilizadora - novo ideal que se propõe, após um período de intensa colonização, essa nova sociedade liberal. "Vulgarizar a ciência", "educar o povo", significa, antes de mais nada, mostrar ou, melhor dizendo, oferecer a natureza em espetáculo.

\section{A fotografia: entre o desenho e o gesso}

$\mathrm{Na}$ metade do século passado, a fotografia representa com certeza uma inacreditável aventura e abertura, científica e humana. Todavia, ela apenas há pouco nascera, de forma que ainda engatinha. Os processos de sensibilização das placas são complexos, lentos e precários. Faltam-lhe, ainda, dispositivos e obturadores mais precisos e velozes, aperfeiçoamentos de suas lentes. Padece, sobretudo, da sua impossibilidade de reprodução do único positivo que o daguerreótipo oferece. O daguerreótipo é, dessa maneira, uma meia-resposta num século que procura a instantaneidade, "o momento sonhado". Esse momento advirá, na França, no começo da década de 1980, quando Albert Londe e Étienne-Jules Marey se utilizarão dos novos suportes emulsionados pela gelatina-brometo de prata $^{18}$ e, sobretudo, desenvolverão, com 
requinte e engenhosidade, os seus obturadores mecânicos e dispositivos cronofotográficos ${ }^{19}$.

Apesar da fotografia perambular, na época, por todas as partes do mundo e por todas as ciências, ela permanecia um enigma. Étienne Serres dizia: "A representação fiel dos tipos humanos está na base da antropologia; obtém-se através de dois procedimentos que nada deixam a desejar: o daguerreótipo, de um lado, e a moldagem dos bustos em gesso, do outro". Acrescentava, todavia: "De uma precisão bem maior do que o daguerreótipo, são as reproduções dos tipos pela moldagem de gesso ao vivo, na medida em que reproduzem ao mesmo tempo o tipo e as dimensões da cabeça, do pescoço e dos ombros. Uma vez obtidas essas dimensões, torna-se fácil, a partir da correlação das partes, deduzir as dimensões daquelas que o gesso não pôde representar" (La Lumière, 1852, n.33: 130, grifos nossos). Será que Étienne Serres estava tão convencido do potencial da fotografia quando reiterava a sua confiança nas moldagens de gesso? Provavelmente não.

Na época, o naturalista, anatomista ou zoólogo dispõe de três principais suportes imagéticos. Serres os menciona: desenhos (pinturas ou gravuras), as moldagens de gesso e a nascente fotografia.

Com relação aos desenhos, os comentários da época se entrecruzam: "Os artistas, acostumados a representar, sem cessar, o tipo europeu, são incapazes, na maioria dos casos, de traçar o retrato e a verdadeira fisionomia de um selvagem da América ou de um insular da Polinésia. Tendem invencivelmente a dotá-lo, mais ou menos, da marca das fisionomias que têm o costume de reproduzir mediante o desenho" (Blanchard, 1841-1854: 7-8). Como dirá o próprio Serres: “Os viajantes nos transmitiram os tipos americanos e o fizeram de uma maneira artística: quase sempre as figuras que se encontram nas suas obras são os tipos europeus vestidos à americana. A arte brilha, sem dúvida, mas à custa da realidade".

Mas a questão conduz mais longe: “Quando o zoólogo faz um desenho, ele representa apenas o que ele observa no seu modelo e, conseqüen- 
Revista de Antropologia, São Paulo, USP, 2001, v. 44 nº 2.

temente, a imagem traçada pelo seu lápis traduz somente a idéia mais ou menos completa que ele formou da coisa a ser representada, de tal modo que é pouco provável que a figura assim obtida mostre com clareza os caracteres que o autor não tiver levado em conta”. O desenho, em outros termos, é tão subjetivo quanto a fotografia (o que, no entanto, não se diz, na época), a qual, todavia, guarda essa particularidade que, com muita perspicácia, revela seu colega Milne Edwards: "Além de ser uma reprodução fiel da realidade", uma "imagem fotográfica bem feita oferece não somente o que o autor pessoalmente viu e quis representar, mas, também, tudo aquilo que está realmente visível no objeto assim reproduzido. Um outro naturalista poderá desta maneira captar dados que o primeiro não terá percebido e, graças à imagem, fazer verdadeiras descobertas, como faria observando o objeto ao natural".

Belo demais, carregando a presença e a subjetividade do artista, o desenho permanece na época um tanto suspeito, em termos antropológicos. Procurava-se provas, medições exatas. Até que a fotografia pudesse afastar essas ilusões. Era, no entanto, um potencial ainda insuficientemente explorado em termos de manuseio e de performance. Além disso, a fotografia era achatada e reduzia o mundo a duas dimensões. O gesso oferecia dessa maneira aos cientistas outras possibilidades de exatidão: os volumes e as dimensões diretamente mensuráveis.

Essa técnica secular da moldagem consistia em tomar, a partir de um original (objeto ou pessoa) existente, um molde ou concavidade e tirar deste molde (por escoamento ou estampagem) uma prova, um positivo. Como, na época, se fazia o molde de uma cabeça?

A cabeça do indivíduo (...) deitada horizontalmente, repousava numa espécie de caixa chanfrada para o pescoço e preenchida até a metade com gesso muito líquido. $\mathrm{O}$ artista deixava endurecer o fundo ao mesmo tempo que divertia o seu paciente. Quando já tinha, por completo, toda sua metade pósocular acabada, então, ele apressava-se em confeccionar com um gesso fortemente salgado (para acelerar o processo de endurecimento) a película facial, rapidamente cortada com um fio em dois quartos simétricos. (Hamy, 1906: 268) 
A moldagem era a "fotografia de gesso", um original de segundo grau. Ela será utilizada, ao lado da fotografia, enquanto a antropologia continuar se impondo como tarefa o estudo da espécie e das raças humanas. Essas moldagens serão executadas em Paris ou em Londres sobre sujeitos "exóticos" de passagem e, de maneira mais geral, realizadas por ocasião de expedições longínquas. Serão moldagens de todo tipo, executadas sobre o ser vivo: moldagens da cabeça e das diversas partes do corpo humano: mãos, pés, mamas, joelhos, umbigos, órgãos genitais etc., às vezes, o corpo inteiro.

Um bom exemplo desta prática nos foi deixado pelo médicoantropólogo Daniel-Jules Hyades que participou da Missão Científica do Cabo Horn (setembro 1882-setembro 1883). Numa carta enviada ao seu colega F. Delisle, Hyades conta o que realiza no seu laboratório de história natural, que tinha construído junto à missão estabelecida na Baía de Orange:

Chegaram todos (os habitantes da Terra do Fogo) a posar como admiráveis modelos, e disto vocês têm conhecimento através das fotografias que mandei ao Sr. de Quatrefagues. No tocante às mensurações, consegui, com a ajuda de uma mãe, cumprir todas as indicações das folhas do laboratório do Muséum sobre uma criança com apenas dois anos de idade; sobre a primeira cabeça que moldei, os cordões, tendo-se rompido, tive que quebrar o gesso com um martelo; desta provação, o sujeito saiu todo sorridente e pedindo que a moldagem, logo, fosse reiniciada (...) até que obtive sem dificuldade, tanto por parte dos homens como das mulheres, pagando o sacrifício de seu pudor, excelentes moldagens dos órgãos genitais externos. Não falo das numerosas moldagens dos membros e das extremidades (...). Consumi, quase sem perda, os duzentos quilogramas de gesso que tinha levado; se receber a nova provisão que pedi pelo último correio, espero conseguir moldar sujeitos inteiros. (1883)

As moldagens eram impressões diretas, peças (testemunhais), marcas registradas sobre o corpo real de um sujeito real (vivo ou morto). Eram - como se dizia, na época- "esculturas" que, pintadas ou não, moldavam a realidade na escala humana, quase puras réplicas, sósias ou fantasmas humanos, realizados, às vezes, em condições mais que duvidosas ${ }^{20}$. Cópias conformes a um original que se tinha tornado ausente, elas 
valiam pela ilusão sensível que restituíam. Frágeis, elas não podiam encontrar outro refúgio a não ser nas salas, nos armários e nos depósitos dos museus, onde centenas, conviviam com esqueletos inteiros e outras chamadas peças "antropológicas".

Pode-se perguntar, hoje, o que a fotografia tinha de tão significativo, na época, a ponto de suplantar o desenho e relegar, pouco a pouco, as moldagens de gesso? Os textos que analisamos nos forneceram, é verdade, uma série de respostas. Colocamos, todavia, a pergunta num outro patamar reflexivo. Qual será, nos quadros de uma antropologia que, hoje, questiona o imperialismo da verbalidade na elaboração de seu discurso, o lugar da imagética num mundo onde, em toda parte, a imagem se faz presente? Presente não mais e apenas como prova, índice ou réplica em vista a uma demonstração "objetiva” da realidade e, sim, presente enquanto "molde" cognitivo que vem definindo os seres humanos e as estruturas de suas inter-relações sociais. De que imagens e de que suportes imagéticos precisaremos para entender os homens e as sociedades que se constróem com elas? Deslocando os termos de uma época, a questão se colocaria da seguinte maneira: como e através de que suportes novos chegaremos a entender a "espécie" humana e as "raças", todas devotas ao expansionismo imagético e informático? De que novas representações precisaremos? A Vênus hotentote servirá de horizonte a esta última reflexão.

\section{A Vênus hotentote}

As expedições científicas do século XIX não brilhavam pela natureza de suas finalidades. Por certo, ia-se ao encontro do "outro", para conhecê-lo melhor mas, sobretudo, para poder engoli-lo com mais segurança. Pedia-se, dessa maneira, que viajantes voltassem de ultramar com "amostras" preciosas: desenhos, moldagens e fotografias. Parece, todavia, que no final do século esses índices não eram suficientemente eloqüentes. Queria-se mais. Precisava-se aproximar o selvagem do 
civilizado: vê-lo, enfim, a olho nu, de carne e osso, e oferecê-lo em espetáculo público. Através de que meios escusos e ao preço de quantas mortes? Sem dúvida, a história nos dirá isso mais claramente um dia. Uma coisa é certa: desde os meados do século XIX, multiplicam-se essas presenças "exóticas" sobre os palcos de grandes cidades como Londres, Paris, Hamburgo e Viena.

La Lumière fornecerá todas as informações necessárias ao que diz respeito à existência de negros miam-miams, africanos com rabo, que “outros escravos negros do Brasil já conheciam” (La Lumière, 1852, n. 34: 134). O jornal abrirá suas colunas a longas descrições de cientistas sobre o perfil físico e mental de um casal de dois jovens astecas liliputianos vindo de Londres ${ }^{21}$, enquanto, em Paris, dois núbios, de "uma espécie ainda tão pouco conhecida" e que cuidando de um hipopótamo no Muséum d'Histoire Naturelle, despertam "grande curiosidade do público ao mesmo tempo em que abrem um amplo campo de estudo para a ciência zoológica" (1856, n.29: 114 e n.32: 126). Devemos acrescentar a presença (em 1856) de chefes índios canadenses (idem) e, mais tarde (em 1881), de mais de dez Fujianos, enjaulados no "Jardim Zoológico de Aclimatação" de Paris ${ }^{22}$, um jardim criado para o estudo e o conhecimento de animais exóticos e de plantas que se tornou, desde 1877, sob a direção de Albert Geoffroy de Saint-Hilaire, um lugar de exibição dos selvagens.

É nesse ambiente tão positivista quanto exibicionista e etnocêntrico que temos de pensar as três figuras da Vênus hotentote ${ }^{23}$. A primeira foi moldada ao vivo, em 1815, pelo médico Cuvier (Figura 1). 
Revista de Antropologia, São Paulo, USP, 2001, v. 44 nº 2.

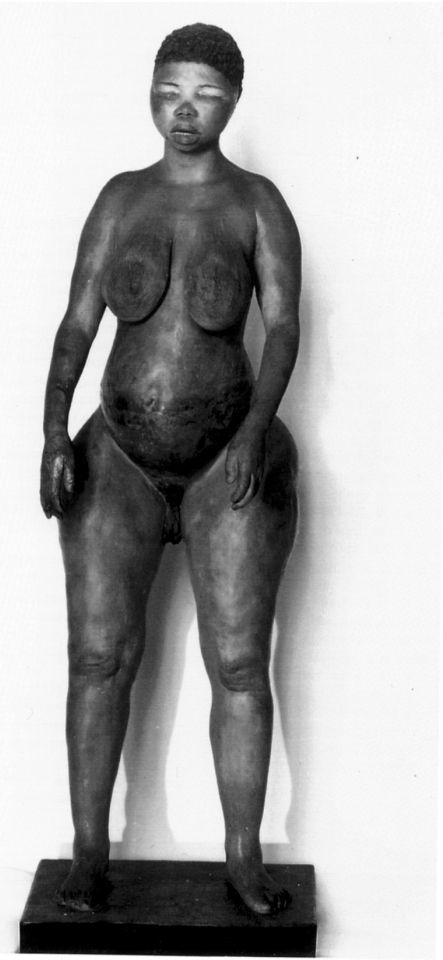

Figura 1: Ateliê do Muséum. A "Vênus hotentote", gesso pintado, 1815; Paris, Museu do Homem, laboratório de antropologia.

Esta mulher originária da África austral, sujeito das observações de Cuvier, tinha sido "trazida do Cabo" quando tinha uns dez anos de idade. Quando ele a viu pela primeira vez em Paris, "ela acreditava ter 26 anos". Um inglês a tinha feito acreditar que ganharia uma grande fortuna, caso viesse a se oferecer à curiosidade dos europeus, mas acabou deixando-a com um mostrador de animais de Paris, na casa do qual ela morreu, alcoólatra, de varíola. Quando, em 1816, Cuvier fez sua autópsia, concluiu que se as "hotentotes" faziam parte da espécie humana eram dotadas de particularidades raciais tais como um amontoado gorduroso nas coxas e o "avental", isto é, uma hipertrofiada parte 
da vulva interpretada como testemunho de hipersexualidade (Roquebert, 1994: 10). No espírito do público, Saartje se tornara a mulher africana "típica".

É a mesma Saartje Baartman que reencontramos, num duplo desenho (de face e de perfil) (Figura 2) publicado, oito anos depois (1824), pelo anatomista Geoffroy de Saint-Hilaire e pelo próprio Cuvier, num livro intitulado História natural dos mamiferos com figuras originais, coloridas a partir de animais vivos, publicado sob a autoridade da administração do Muséum d'Histoire Naturelle. Nele, Saartje Baartman aparecia como uma das 120 espécies de mamíferos ${ }^{24}$.
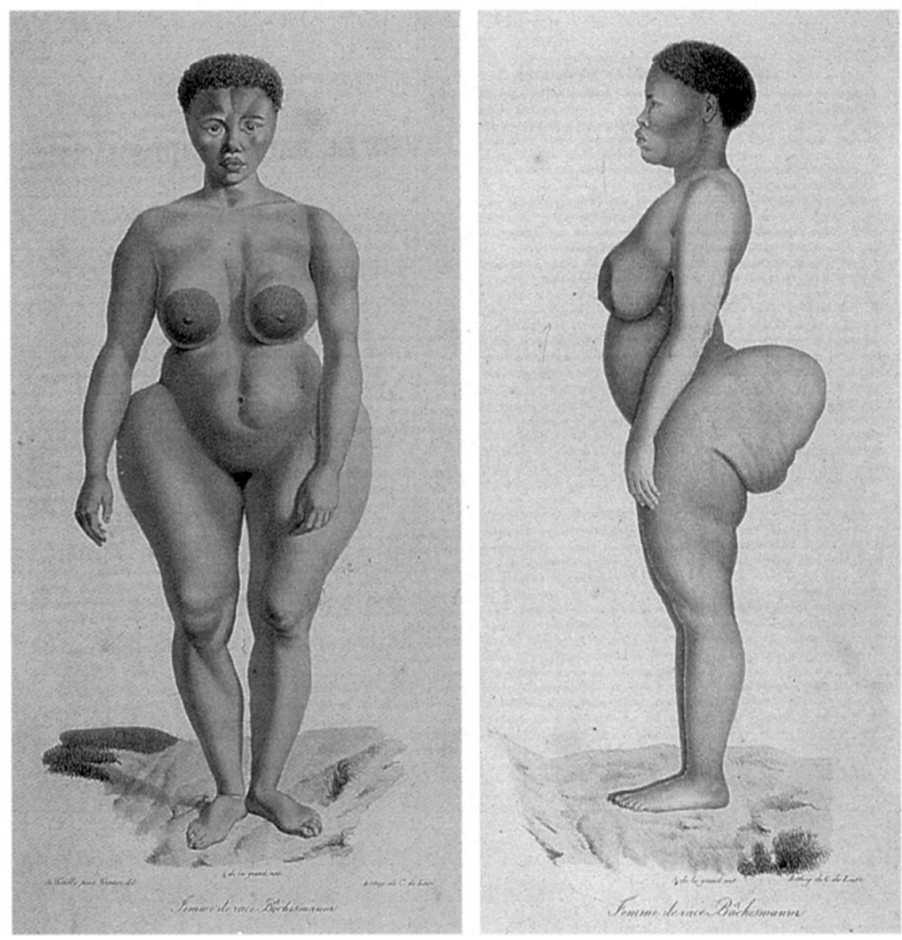

Figura 2: Étienne Geoffroy Saint-Hilaire. A História natural dos mamiferos com figuras originais coloridas, desenhadas a partir de animais vivos, Paris, A. Belin, 1824, tomo 1, pranchas 1 e 2; Paris, Muséum d'Histoire Naturelle, biblioteca. 
Será que precisamos da fotografia de Stinée, conterrânea de Saartje Baartman, fotografada apenas de costas (Figura 3) em 1855 por Louis Rousseau, ajudante fotógrafo no Muséum, para nos convencermos das questões da esteatopigia das nádegas (brancas) ou para que ela nos revele que o topless era uma virtude natural da mulher hotentote? Envolto por luzes e sombras, o cientista do século XIX era um aprendiz. Talvez, pensava poder ser o voyeur universal. Como nós hoje em dia, esperava por um novo eclipse.

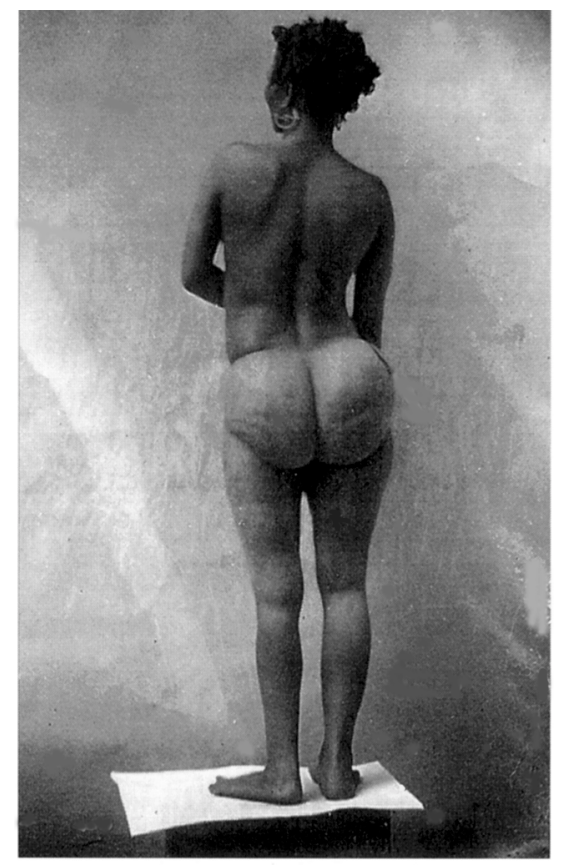

Figura 3: Louis Rousseau (o fiel servidor de Étienne Serres no Muséum). Stinée, fotografia, 1855; Paris, Museu do Homem, fototeca. 


\section{“O que a fotografia pode fazer pela antropologia?"}

Eis a questão que propunha aos leitores do La Lumière, Ernest Conduché, crítico e colaborador assíduo do semanário, num artigo empolgado, redigido em 1855:

Existem poucas questões científicas para as quais a fotografia pode oferecer tantos subsídios (materiais). É que, com efeito, a ciência das raças humanas se compõe de uma multidão de elementos fugazes, inapreensíveis. Todos esses elementos vêm se fixar por si mesmos sobre o papel graças à fotografia. Por outro lado (...) faz-se necessário que a fotografia venha ao socorro da antropologia. Sem isto, ela permanecerá, por muito tempo ainda, o que ela é hoje. Pois será que se pode dizer que desde Linné, Blumenbach, etc., etc., ela se tenha colocado ao nível das outras ciências? Evidentemente não. Desde aquela época, apenas tentativas, sobressaltos, mas nada contínuo. No momento em que vivemos os progressos da humanidade são incalculáveis; parece que uma febre ardente nos força a deixar os costumes de nossos ancestrais. As invenções modernas mudam a face do globo; numa só palavra, e voltando ao nosso assunto, eis que vivemos o momento quando a mistura das raças vai se realizar numa grande escala. Agora, onde se encontra o ponto vital da ciência antropológica? É precisamente no saber desenredar, no meio dessas misturas, o que pertence a uma raça e o que pertence a outra. E que meio mais seguro, que base mais sólida que pode possuir o etnólogo, a não ser uma multidão de provas fotográficas realizadas em todo lugar (...)? Eis o caos que a antropologia tem que desvendar, e ainda está longe o tempo em que se poderá dizer com certeza o que se diz de nossos animais domésticos: eis tal raça, tal variedade. Sem a fotografia, esse momento se adiaria ainda mais. (n.13: 50-1)

A antropologia francesa de meados do século passado é uma antropologia pobre e que titubeia. Situa-se bem aquém do "nível das outras ciências" e precisa de "socorro". Tanto Conduché como os novos portavozes das ciências naturais - a maioria, médicos, naturalistas, zoólogosimaginam e têm certeza de que o advento da fotografia revolucionará e resolverá tudo: "Que meio mais seguro, que base mais sólida pode possuir o etnologista a não ser uma multidão de provas fotográficas realizadas em todo lugar?”. Sonhava-se com o mapeamento visual da humanidade. 
Revista de Antropologia, São Paulo, USP, 2001, v. 44 nº 2.

Com certeza a fotografia vai desempenhar o seu papel multiplicando, aos milhares, os registros dos tipos e das raças humanas. Dito isto, ela permanecerá durante mais de cinqüenta anos subutilizada, atrelada que está a um horizonte de investigações das "superfícies" da espécie humana. Essa primeira antropologia visual não passará de uma tentativa, mais ou menos bem-sucedida, de uma aproximação do corpo visível e da exterioridade do ser humano. Um corpo, na maioria dos casos, desnudado, visto de frente, de perfil e de costas, do qual se mede, também, o crânio, para comparar o "conjunto" aos padrões do europeu industrializado. Uma antropologia comparativa à procura de signos, de marcas, de inscrições, de diferenças cravadas à superfície da pele humana e capazes de serem registrados fielmente através de uma outra pele: a película.

Esse esforço generalizado de "tipologização" da espécie humana conduzirá a uma série de outros experimentos: fotografias antropométricas (Thomas Henry Huxley, John Lamprey); fotografias "compósitas" (Francis Galton, Arthur Batut); tipologia das doenças mentais e nervosas (Hugh W. Diamond, John Conolly, Jean-Marie Charcot e Albert Londe); ou identificação das personalidades criminosas, assassinas, loucas (Cesare Lombroso). Chegará, na virada do século, a fornecer a um medíocre mas teimoso funcionário da Prefeitura de Paris, Alphonse Bertillon, o material indicial suficiente para sofisticar mais ainda a fotografia sinalética e judiciária ${ }^{25}$. A fotografia não era mais e apenas um campo de índices. Tinha-se tornado uma imagem capaz de denunciar e de acusar (Phéline, 1985).

Esse primeiro e longo percurso da antropologia visual poderia ser qualificado de primeira cegueira antropológica. Ao buscar provas e, ao mesmo tempo, suas credenciais, a antropologia física não conseguiu descobrir nem as primeiras nem as últimas. Teria de atravessar as epidermes humanas e penetrar no que seria a verdadeira carne. É o que tentará fazer a antropologia social e cultural.

Curiosamente, depois de seu nascimento, esse outro ramo da antropologia, que tem como objeto a organização social e os dispositivos culturais 
que regem os grupos humanos, vai progressivamente dando as costas à fotografia. Sem nunca renegar a necessidade de uma observação direta, ele fará desta, e cada vez mais, uma espécie de prelúdio, uma muleta, reservando, ao processo de textualização dos fenômenos socioculturais observados, o lugar proeminente e quase "sagrado" do pensar e do fazer antropológico. Observa-se, com efeito, que a fotografia ao passar do funcionalismo de Bronislaw Malinowski ${ }^{26}$ ao conceito de "estrutura", noção já abstrata nas obras de Evans E. Pritchard e que perderá toda visibilidade direta nos trabalhos estruturalistas de Claude Lévi-Strauss, regrediu drasticamente no campo específico da antropologia social, reduzida que foi, até há pouco, para servir apenas de blocos de ilustrações, de cadernos de diversões exóticas ou de provas justificando claramente que o antropólogo bem "esteve lá”. Dizer que a fotografia não interessava mais aos antropólogos representaria um exagero, mas pensar que ela lhes era cada vez menos útil levanta outras questões: quais os impactos, os condicionamentos, os imperativos que todo projeto teórico antropológico (evolucionismo, funcionalismo, cultura e personalidade, estruturalismo ect.) crava na visualidade do próprio pesquisador? Mas, também, quais seriam, no campo da antropologia, as virtudes da escrita que a visualidade fotográfica não teria? Ou, ainda, quais seriam, no mesmo campo da antropologia cultural, as potencialidades da fotografia, singulares com relação à escrita, mas que ela não soube ainda alcançar ou desenvolver suficientemente? O que viria a definir e a esclarecer sua necessária complementaridade ${ }^{27}$ ?

\section{Notas}

1 No momento da conclusão deste trabalho, tomamos conhecimento da síntese de uma tese de DEA, elaborada sob a orientação de André Rouillé e de Sylvain Maresca, defendida em setembro de 1995 na Universidade de Paris VIII, publicada parcialmente pelo seu autor, Pierre-Jerôme Jehel, sob o título "Fotografia e antropologia na França no século XIX”, 1998. Um trabalho que julgamos muito interessante e feliz na medida em que encara as relações entre "fotografia e 
antropologia" durante todo o século XIX, de um ponto de vista, muitas vezes, complementar com relação à nossa pesquisa.

Nossos agradecimentos, também, à Fraya Frehse.

2 Para a história deste período, consultamos, entre outros, o trabalho de Plessis (1979). No tocante à inserção da fotografia na história do Segundo Império, remetemo-nos ao excelente ensaio de Rouillé (1982) e ao livro organizado por Fabris (1991).

3 A previsão era quase exata: no começo de 1968 a população francesa ultrapassava os 50 milhões, apesar das duas guerras mundiais.

4 "Passage" é a palavra utilizada no começo do século XIX na França para designar as estreitas ruas privadas que atravessam o interior das grandes ilhas de habitações. Objeto da especulação privada nos centros das grandes cidades da Europa, as "passagens" são os lugares onde as pessoas se encontram, fazem suas compras, flanam e se divertem. Ver Geist (1988) e o grande projeto de livro de Benjamin (1989).

5 "As realizações de Haussmann em Paris respondem a um duplo objetivo: a manutenção da ordem, pela destruição das vielas propícias a barricadas, e o assentamento de importantes casernas de onde irradiam avenidas retilíneas permitindo os tiros da artilharia ou as cargas de cavalaria, e a criação de um novo quadro urbano para a classe dominante, com seus imóveis opulentos, suas grandes lojas, seus grandes bancos e suas estações” (Butler \& Noisette, 1983: 19)

6 Notar-se-á a tríplice nomenclatura: "os operários do pensamento", "os mecânicos”, "os químicos".

7 Beaugé (1995) escreve com muita pertinência: "Só quando se tiver reconhecido que a fotografia se desenvolve num espaço de saber muito profundamente marcado pelo positivismo - o qual se define principalmente por uma postura que dá proeminência aos 'dados' da observação - se conseguirá entrever a dificuldade: os 'fatos científicos' nunca serão redutíveis aos 'dados imediatos da percepção', de tal modo que os problemas que levanta a utilização de uma verdadeira epistemologia gráfica estão longe de se resolverem no décalage existente 
entre o que se concebe e o que se observa" (vol. 1: 16). Remetemos a dois trabalhos fundamentais de Kremer-Marietti (1982 e 1983).

8 Broc (1988) registra, para a única África Equatorial Francesa, 675 exploradores ao longo do século. Entre eles: soldados, missionários, cientistas, colonos, prospectores, caçadores, aventureiros.

9 Londres (1851, 1862), Paris (1855, 1867, 1878, 1889), Viena (1873), Filadélfia (1876), Chicago (1893), Bruxelas (1897). Sobre o assunto: Turazzi (1995) e Pinot de Villechenon (1992).

10 Entre eles e desde 1838: Pierre Flourens, Étienne Serres, Armand de Quatrefages, Paul Broca, Paul Topinard, Ernest-Théodore Hamy. Antes deles, nomes como os de Georges Cuvier (1769-1832) e Étienne Geoffroy de Saint-Hilaire (17721844), que reencontraremos no final do artigo, falando da Vênus hotentote.

11 "O estado no qual vemos todos os animais é produto da composição crescente da organização que tende a formar uma gradação regular” (os grifos são nossos).

12 Obra iniciada desde 1837, logo após uma viagem que fez em torno do mundo (dezembro de 1831 a outubro de 1836), com permanência de vários meses no Brasil (Fernando de Noronha, Bahia, Rio de Janeiro).

13 Será que Marx tomou conhecimento do livro ("difícil de ser encontrado em Londres”, dirá Engels) que, em 1877, publica Lewis. H. Morgan: Ancient Society, or Researches in the Lines of Human Progress from Savagery througt Barbarism to Civilization? Friedrich Engels, pelo menos, nos deixa no "Prefácio" da primeira edição (1884) do seu A origem da família, da propriedade privada e do estado, os seguintes comentários: "O fato é que Morgan descobriu, à sua maneira, na América, a concepção materialista da história, descoberta por Marx quarenta anos antes, e, pela comparação entre barbárie e civilização, essa concepção o conduziu, no tocante aos seus aspectos capitais, aos mesmos resultados que Marx" (1946: VII).

14 O Muséum d'Histoire Naturelle foi fundado em 1793 sobre o sítio do Jardin du Roi. “A partir do Muséum foi criado, em 1878, o Musée d’Ethnographie du Trocadéro, que se transformará em 1937 no Musée de L'Homme” (Jehel, 1998: 125). 
Revista de Antropologia, São Paulo, USP, 2001, v. 44 nº 2.

15 Notar-se-á que Serres retoma inteiramente o modelo do mito bíblico: relato da criação até a dispersão dos povos em Babel (Gênesis 2,4 a 11,9).

16 Essas representações visuais (gravuras, desenhos, mapas, fotografias, desenhos obtidos por meios mecânicos, gráficos, estatísticos) são, na linguagem da época, todas designadas como "figuras". Essas "figuras" devem "acompanhar" os textos e, de certo modo, suprir as descrições textuais, demasiadamente longas e sempre sujeitas à falta de objetividade. Uma visão e uma concepção do papel da fotografia, nos meios antropológicos, bem diferentes daquela que se formará, setenta anos depois, reduzida que será a uma mera ilustração ou prova de que, efetivamente, o antropólogo "esteve lá". Remetemos ao interessante artigo de Dias (1997).

17 "Há sete meses apenas um naturalista do Muséum, o Sr. Rousseau, concebia a idéia de aplicar a fotografia à iconografia zoológica, mas ele não era fotógrafo. Para os seus primeiros experimentos, precisou recorrer aos irmãos Bisson. Os resultados obtidos foram tão satisfatórios, que fizeram os autores chamarem a atenção da Academia. Pouco tempo depois (14 de junho de 1853), MilneEdwards, professor de zoologia no Muséum propunha à Academia, em nome da Comissão de que era relator, não somente encorajar os autores a prosseguirem com seus trabalhos que tinham ocasionado consideráveis despesas, mas ainda colocar à disposição destes instrumentos novos, considerados necessários para suas experiências; pois, dizia o Sr. relator: 'Se tiverem à sua disposição instrumentos convenientes e os meios de experimentação necessários, pensamos que chegarão rapidamente a resultados muito úteis para a ciência"' (La Lumière, 1853, n. 48: 190).

18 Suporte que - embora descoberto, em 1871, por Richard Leach Maddox (18161902) - somente terá ultrapassado seu estágio experimental no início dos anos 80. Processo seco, conservável e de fácil preparo, ele permite um tempo de pose da ordem de um segundo em condições difíceis. Teve de dispensar rapidamente toda a atravancadora bagagem da qual precisava o fotógrafo trabalhando com a chapa úmida de colódio, abrindo definitivamente o espaço à geração de um leque de aparelhos portáteis.

19 Remetemos a Bernard \& Gunthert (1993) e a Marey (1994). Ver ainda nosso breve artigo "Entre a arte, a ciência e o delírio: a fotografia médica francesa na segunda metade do século XIX". 
20 "Salvage [o nome do artista] executou magníficas moldagens sobre dois soldados mortos de morte violenta, que dissecou, colocou na postura bem conhecida do gladiador, e fez congelar antes de moldá-los" (La Lumière, 1858, n.51: 202).

21 "Sem dúvida nenhuma, essas crianças adolescentes representam um dos mais baixos degraus do desenvolvimento do homem (...) essas crianças devem ser consideradas como idiotas ou cretinas e, talvez, até, ambos (...). Será possível ver logo que são as duas mais raras amostras de anomalias que existem neste mundo. Que achado para os teratólogos e os antropólogos!' (La Lumière, 1853, n.33: 130-1; 1855, n.29: 114 e n.32: 127).

22 O "Jardim de Aclimatação" ou primeiro Jardim Zoológico de Paris: "Em 1854, três científicos obtiveram do Imperador Napoleão III, 15 hectares do Bois de Boulogne para, nele, aclimatar espécies animais que possam com vantagem dar sua força, sua carne, sua lã, seus produtos de todo tipo à indústria e ao comércio, ou servir aos nossos divertimentos" (Inauguração da Fundação Imperial de Aclimatação, 6 de outubro de 1854).

23 Designada erradamente, na época, como da raça bosquímana.

24 As duas figuras são pranchas realizadas por Léon de Wailly e litografadas por C. de Last. Na História natural dos mamíferos, Cuvier nota: "a enorme protuberância de suas coxas e a aparência brutal de seu rosto. Seus movimentos tinham algo que lembrava os do macaco. Ela foi estudada e medida (quatro pés, seis polegadas e sete linhas) quando 'na primavera de 1815 , tendo sido conduzida ao Jardin $d u$ Roi, teve a complacência de se despir e de se deixar pintar, na sua nudez"'. Remetemo-nos a Roquebert (1994: 9).

25 Fotografia sinalética que aparece desde 1850. Ver La Lumière (1853: 40, 167; 1854: 112-3, 159, 164; 1855: 20, 50, 76; 1856: 126).

26 Bronislaw Malinowski que, nas três monografias que dedica aos nativos das Ilhas Trobiand, faz um uso constante e cada vez maior da fotografia. Remetemos à nossa pesquisa (Samain, 1995).

27 Sobre esses assuntos dispomos hoje de uma importante bibliografia em língua portuguesa. Sem ser exaustivos, assinalamos cinco revistas de peso: Boletim do Centro de Memória da Unicamp (em especial, n.10), 1993; Cadernos de Antropologia e 
Revista de Antropologia, São Paulo, USP, 2001, v. 44 nº 2.

Imagem, Rio de Janeiro, UERJ (desde 1995); Cadernos de Campo. Revista dos alunos de pós-graduação em Antropologia da Universidade de São Paulo (desde 1991); Horizontes Antropológicos - Antropologia Visual, UFRGS (em especial, n. 2), 1995; Revista de Antropologia da USP.

\section{Bibliografia}

BEAUGÈ, G.

1995 "Préface" et "Sommaire", in La Lumière. Beaux Arts, Héliographie, Sciences, Aix-en-Provence, Jeanne Laffite, 2 vol.

BENJAMIN, W.

1989

Paris, capitale du XIX siècle de livre despassages, Paris, Cerf.

BERNARD, D. \& GUNTHERT, A.

L'instant rêvé. Albert Londe, Nîmes, Jacqueline Chambon.

BLANCHARD, E.

1841-1854 Voyages au Pôle Sud et dans l'Océanie sur les corvettes L'Astrolabe et la Zélée exécutés par ordre du roi pendant les années 1837, 1838, 1839 et 1840, Paris, Gide, 27 vol., 7 atlas, Anthropologie.

BROC, $\mathrm{N}$.

1988 Dictionnaire illustré des explorateurs français du XIX siècle, Paris, Comité des Travaux Historiques et Scientifiques.

BUTLER, R. \& NOISETTE, P.

1983 Le logement social en France. 1815-1981, Paris, Le Découverte-Maspero.

CRARY, J.

L'art de l'observateur. Vision et modernité au XIX siècle, Nîmes, Jacqueline Chambon.

DIAS, $\mathrm{N}$.

“Images et savoir anthropologique au XIX siècle”, Gradhiva, n. 22: 87-97. 
DUCHET, M.

Anthropologie et Histoire au siècle des lumières. Buffon, Voltaire, Rousseau, Helvétius, Diderot, Paris, François Maspero.

ENGELS, F.

1946

L'origine de la famille, de la propriété priveé et de l'État, Paris, Alfred Costes.

FABRIS, A. (ORG.)

1991

Fotografia. Usos e funcões no século XIX, São Paulo, Edusp.

GEIST, J. F.

1988 Le passage. Un type architectural du XIX siècle, Liège/Bruxelles, Pierre Mardaga.

HAMY, E.-T.

1906 "La collection anthropologique du Muséum d'Histoire Naturelle", L'Anthropologie, t. XVII.

HYADES, D.-J.

1883

"Carta ao Senhor F. Delisle de 24 de abril de 1883", Bulletin de la Société d'Anthropologie de Paris, 5 jui., pp. 617-19.

JEHEL, P.-J.

1998 "Fotografia e antropologia na França no século XIX", Cadernos de Antropologia e Imagem, n.6, pp. 123-37.

KREMER-MARIETTI, A.

1982 Entre le signe et l'histoire. L'Anthropologie positiviste d'Auguste Comte, Paris, Klincksieck.

1983 Le concept de science positive. Ses tenants et ses aboutissants dans les structures anthropologiques du positivisme, Paris, Klincksiek.

LA LUMIÈRE

1851-1867 La Lumière, Paris.

MAREY, E.-J.

Le mouvement, Nîmes, Jacqueline Chambon. 
Revista de Antropologia, São Paulo, USP, 2001, v. 44 nº 2.

MARX, K.

1965 Oenvres. Economie I, Paris, Gallimard, Bibliothèque de la Pléiade.

NADAR

1994 Quand j'etais photographe, Paris, Seuil.

PHÉLINE, C.

1985 L'image accusatrice, Les Cabiers de la Photographie, Paris, n. 17, 1985.

PINOT DE VILLECHENON, F.

1992 Les expositions universelles, Paris, Presses Universitaires de France.

PLESSIS, A.

1979 De la fête impériale au mur des fédérés. 1852-1871, Paris, Seuil.

ROQUEBERT, A.

1994 "La sculpture ethnographique au XIX siècle, objet de mission ou oeuvre de musée", in La sculpture ethnographique. De la Vénus hottentote à la Tehura de Gauguin, Paris, Réunion des Musées Nationaux.

ROUILLÉ, A.

1982 L'Empire de la Photographie. Photographie etpouvoir bourgeois 1839-1870, Paris, Le Sycomore.

SAMAIN, É.

1993 "Entre a arte, a ciência e o delírio: a fotografia médica francesa na segunda metade do século XIX", Boletim do Centro de Memória (Unicamp), vol. 5 (10): 11-32.

1995

"Bronislaw Malinowski e a fotografia antropológica", in Pluralismo, espaço social epesquisa, São Paulo, ANPOCS/Hucitec, pp. 287-321.

TURAZZI, M. I.

1995 Poses e Trejeitos. A fotografia e as exposições na era do espetáculo (1839-1889), Rio de Janeiro, Funarte/Rocco. 
ABSTRACT: In the effervescent half ot the nineteenth century, characterized by an order-and-progress fever, a blind belief on rationality and on enlightment, French anthropologists-naturalists discover, besides many other scientists, the heuristic possibilities photography could offer their "vision" of "anthropology" as an effort to outline, from an evolucionist point of view, "human species" and races as a whole, and, amidst them, the different types of human beings. La Lumière (1850-1867), the first French journal concentrated on "Photography, Arts and Sciences", has partly been reprinted in 1995. By diving into the columns of this weekly journal, the reader not only gets into contact with the origins of French anthropology, but also discovers the conceptions and beliefs these early scientists shared regarding the new "retina" and technical support photography represented for them. And the reader also discovers how this protesis brings about a new order of seeing, and arises, in terms of an epistemology of knowledge, an interesting questioning regarding two other means of figurative representations usual in the anthropological circles of that time: drawings and mouldings of plaster.

KEY-WORDS: French Visual Anthropology in the nineteenth century, journal La Lumière (France), means of figurative representations, Hottentot Venus. 